\title{
The Analysis of Sustainable Waterfront Development Strategy - The Case of Keelung Port City
}

\author{
Chien-Hua Chen \\ The Administrative Office of Keelung City, Taiwan, R.O.C \\ Email address: \\ k1037@mail.klcg.gov.tw, countryhandchen@yahoo.com.tw
}

To cite this article:

Chien-Hua Chen. The Analysis of Sustainable Waterfront Development Strategy - The Case of Keelung Port City. International Journal of Environmental Protection and Policy. Vol. 3, No. 3, 2015, pp. 65-78. doi: 10.11648/j.ijepp.20150303.12

\begin{abstract}
This paper discusses the phenomenon and historic background of the waterfront development. It emphasizes the need for system programming and sustainable management consideration pursuing the development of estuarine or coastal land. It also explains that the success or failure of a waterfront development should be evaluated through a set of multi-aspect indexes. According to different types of waterfronts, their spatial needs are also specific. In the paper, based on concepts of Alvin Toffler's Third Wave, the framework of three stages and six types of waterfront development is devised to discuss its evolution and functions. The development strength of waterfront is divided into three degrees originating the sustainable development concept. In development strategy aspect, this paper analyzes the original meaning and content of waterfront development. Finally, Keelung port city is then taken as an example of to illustrate the waterfront land use development while examining the problems of its current strategies.
\end{abstract}

Keyword: Waterfront Development, System Programming, Sustainable Management, Development Strategies

\section{The Genesis and Historical Context of the Waterfront Development}

The waterfront is the origin of human culture and economy. A lot of creatures depend on water for life. Mankind is no exception. Therefore, the earliest villages were close to water sources. This was not only because of our dependence on water but also due to traffic concerns. The rise and fall of many cities was related to transportation. In the very beginning, villages close to water turned into fishing villages. In the age of navigation, they became the posts of trade. In the industrial age, they became container ports. The old ports then became the new waterfront appearance. Such a process represents the diversity of waterfront use and its importance to human life and commercial activities [1].

With the advancements in Industrial Revolution Era and shipping communication, many industrial districts are established by the sea, for these industrial products can be efficiently transported. Communication network is established as well. In company with large-sized watercrafts and the advent of information revolution epoch, industrial structure has been altered. Following this, not a few of the new arisen high-tech industry is built in the suburb, instead of utilizing the previous harbor districts, therefore substantive idle land came into being in the waterfront of Post-Industrial Revolution Era. The unused land in the industrial districts and traffic occupation poses many economic and social problems to the urban development. Nevertheless, by reason of their favorable geographical positions in approaching downtown relatively, the land also bears opportunities to the urban development. The influence of the redevelopment of waterfront land caused by industry transformation is cosmopolitan. Hoyle (1999) [2] suggested that the redevelopment of waterfront land is an inevitable global phenomenon for a sustainable developed harbor city, from advanced countries to developing countries from cosmopolitan cities to small towns. And the success experience of Baltimore inner harbor renewal starting at 1960s even became an imitation object to other occident Post-Industrial Revolution countries. Consequently, this tide engulfed Australia, East Asia, Africa, and Latin America.

Hayuth (1998) [1] adopted a comprehensive view in deciphering the development and trend of harbor and city in the Post-Industrial Revolution Era. He finds out that the process of change and interfacial relation between harbor and city pivots the attitudinal transit of the public and the innovation of technology. The change of the two factors brings 
out the spatial, economic and ecological change to the

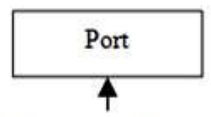

Change of technology and transportation

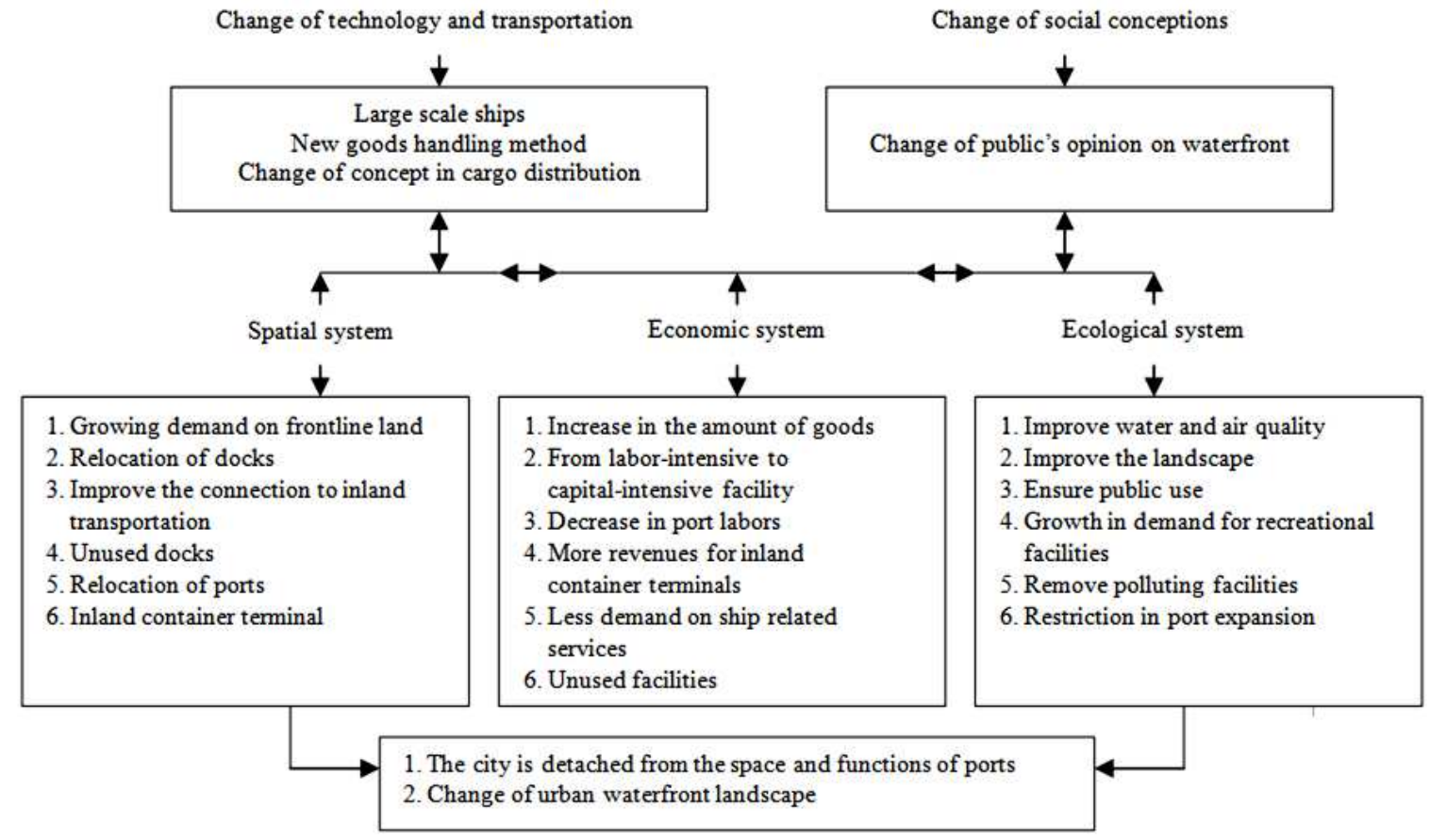

Figure 1. Trend and development of the interface relationship between the port and city in the post-industrial revolution era.

As waterfront land is enormously developed, another view has been proposed which focused on the protection of coast ecology. In the past, the development of estuarine and coast mostly put emphasis on engineering technical, but considerations of system planning and ecologically sustainable management were often ignored. As human beings are realizing the importance of environmental waterfront (See Figure 1).

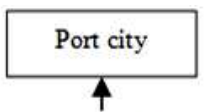

ange of social conceptions

facilities

5. Remove polluting facilitie

6. Restriction in port expansion

Table 1. Summary of coastal control measures and waterfront development process.

protection, it is absolutely necessary to consider the sustainable management of waterfront development in the future. Vallega (2001a)'s [3] further analysis found that global climate change and the Waterfront Recovery Agitation have attracted the international community's attention to the sustainable development of coast, and also catalyzed the international role of waterfront as a global link (See Table 1).

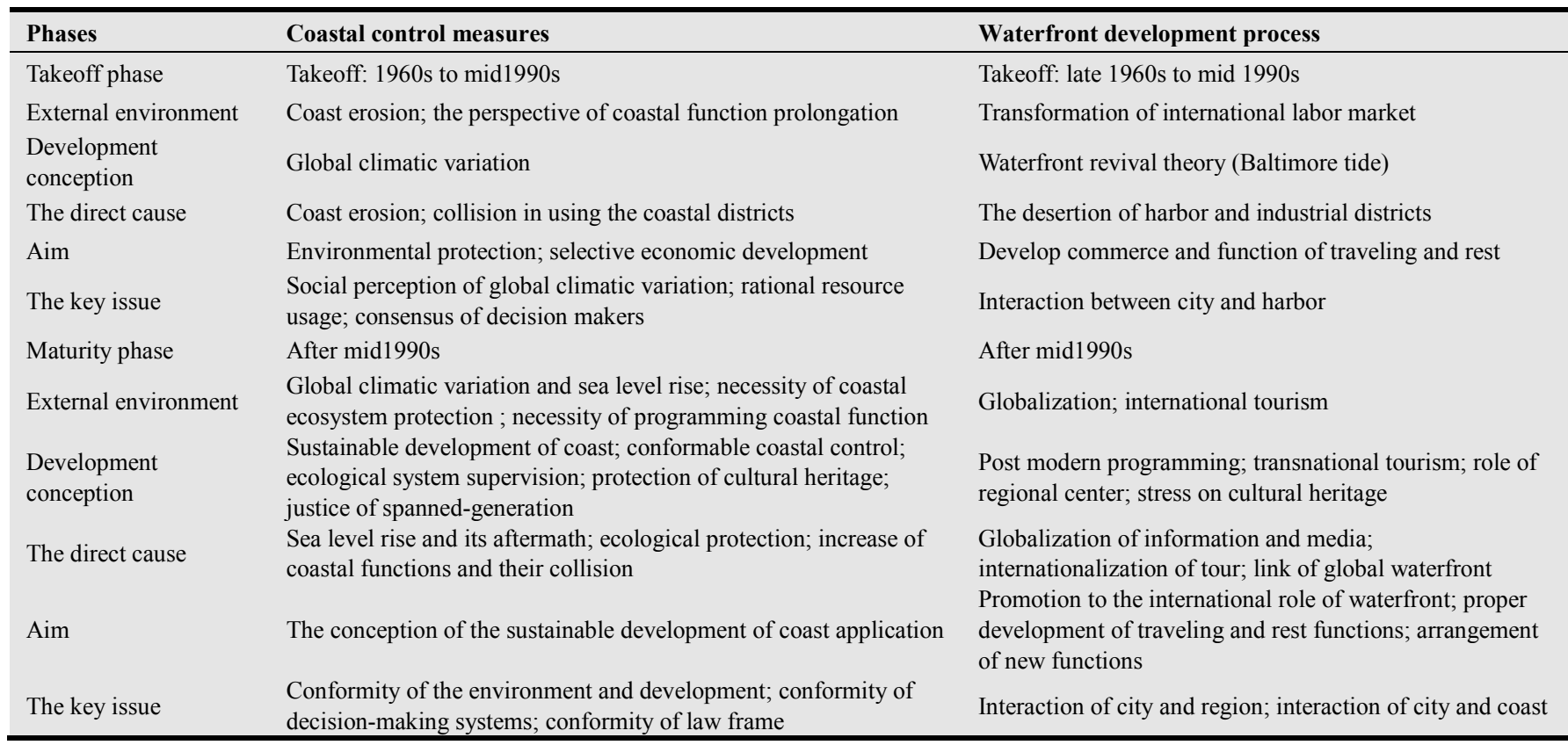


Vallega (2001a) [3] believed that the waterfront century has passed two stages:

1 First stage (1960-1990) with the downfall of modernist, the updated version of waterfront has gained vital importance for saving local GDP and employment rate.

2 The second stage begins at the middle of 1990s, the postmodernism affected by the sustainable development concept rises; under the Chapter 17 of United Nations Agenda 21, the waterfront development and the management of waterfront conformability begins to interact with each other.

The tremendous developments of waterfront, in some perspective, reflect the changes in the global industrial structure as well [4-6]. The transformations of international labor market and the desertion of harbor industrial district in the Post-Industrial Revolution Era catalyze the theory of waterfront revival. The renewal tide of "Baltimore type" creates many waterfronts which focus on the functions of commerce development, travel and rest, and brings about the delicate changes in the interaction between city and harbor [7]. Moreover, the soaring of international tourism caused by the globalization of information and the new arisen industries alike draw the attention of many countries to the potential of touring industry. The post-modern layout not only lays stress on transnational tourist demand, but also takes into account the role of regional center of waterfront. And waterfront's emphasis on cultural heritage, driven by the push of internationalization of tourism, also becomes an important topic [8-9]. The link of global waterfront brings its international role to the light day by day, and proper development of traveling and rest function of waterfront becomes a consensus. The new functions lead the interaction between city and coast to be reinterpreted.

However, simultaneously, just with the vast development of waterfront land, many scholars who concern the ecological environment start to realize the crises of human overuse of resources. First of all, global climatic variation engenders the rise of sea level, and followed by the coast erosion and the collision of the use of coastal land. The consideration of environmental protection appears in the development of waterfront. These factors convince mankind that "selective economic development" is the most favorable alternative to the blessing of him. It becomes a consensus to all the nations that resource should be rationally used. Stress is placed at the coast ecological system protection and comprehensive programming of coastal functions. One by one, the notion of coastal sustainable development, conformability of coast supervision ecological system supervision, cultural heritage protection, and justice of spanned-generation appear [10-14]. The conception of sustainable development, which is paid respect in the development of waterfront, precipitates the conformity of environment and development, the conformity between decision-making systems and the conformity between law frames.

The above description roughly sketched out the development reasons and historical background of waterfront phenomenon; wherein, Hayuth's and Vallega's analysis emphasized the phenomenon of waterfront update in the post-industrial era. In fact, the impact and involved aspects of the development of waterfront are deeply studied on a continuous basis. As making extensive use of waterfront land for economic factors, human beings are also aware of the fragility of the environment, thus in this context the concept of coastal management have emerged. In the future, it is necessary to be more prudent when engaged in waterfront development; wherein, systematic and comprehensive coastal planning and management plays an important role in exerting the function and benefits of waterfront areas, and shall be necessarily taken into consideration for the future development strategy.

\section{Multiple Assessment Standards for Successful Development of Waterfront}

Although waterfront development has become a global trend, but because different countries have different development strategies, the achievement and evaluation of waterfront development were also greatly different. Although there were a lot of successful cases, cases of failure can also be found everywhere [15-18]. As for how to judge whether a waterfront development project is successful, there are different standards from different points of view, and views of judgment from multi-angles and stands have been mentioned in many documents with their own discourse points. In Design and Development of Urban Waterfront it was mentioned that to judge whether a waterfront development project is successful, we need to explore separately from such angles as the municipal government, the public and the development agencies [19].

The book implied that from the angle of municipal movement, there are three main standards to judge whether a project is successful:

1 contribute to economic growth.

2 help to increase employment.

3 help to improve the outlook of a city.

From the angle of the public, there are also three main standards judgment standards:

1 whether the general public can enjoy this construction project.

2 whether the construction project contributes to the city cityscape elegance.

3 whether it is economically advantageous.

In the viewpoint of development institutions, there two main standards:

1 there are enough development profits.

2 to get social recognition.

In addition, in City, Capital and Water it was mentioned that to judge the success of a waterfront development project needs from the angle of the government, the planner team, the developers, and the people [20]. Based on this view, the paper proposed four main categories of assessment criteria, 
and worked out the following table (See Table2):

Table 2. Different Categories of Assessment Criteria.

\begin{tabular}{lllll}
\hline Category & Government & Planner team & Developers & People \\
\hline Position and angle & The public interest & Satisfactory development & Development interests & Improved living standards \\
& $\bullet$ Economic growth & - Planning vision & - Development & Comfortable \\
Assessment criteria & - Increase employment & - Vision of an ideal city & profits & enment \\
& - Improve the outlook of city & - Sustainability development & Living standard \\
\hline
\end{tabular}

The above four categories respectively represent the position and angle of public interest, satisfactory development, development interests, and improved standards of living, and have their different assessment criteria on the so-called success. An ideal waterfront development project is expected to achieve the desired target of each of the above-mentioned four categories. First, the government departments representing the public interest is expected to promote the public interest as the highest priority target, so it is hoped to achieve such effects as economic growth, increasing employment, improvement of city outlook, and etc. as the waterfront development project is promoted. Second, the role of planner team is also very important; a good planner can adhere to the planning ideal, analyze the characteristics and patterns of a city from a professional point of view, propose the future development vision for the city, and if necessary, act as a bridge for the communication between the government departments and other units. In addition, with the environmental and ecological changes, the concept of sustainable development should also be included in the overall development system; as for developers, they naturally take development interests as the most important consideration. Many waterfront development projects, especially large-scale waterfront development projects, need to introduce private capital, in that often non-public sectors have ways to independently bear all the funding and risks; as for whether a waterfront development project is worthy of investment, for developers, the most important assessment criteria is whether there is development profits; in other words, projects with no development profit will be naturally impossible to attract private sector's interest in investment; and usually when spurred by the development profits, the efficiency of the private sector, in general terms, will be improved [21-22]. Finally, the largest number of people represent improved living standards, because the most important judgment standard whether the planning is successful depends on the feelings of people living in that environment. However, we also find that in many development projects, people almost have no influence and even without participation mechanisms and channels; in fact, from many new planning concepts, it is gradually discovered the importance of attention to folk wisdom, but from a practical perspective, we see that the in many development projects, because the development results were not supported and recognized by the people, in the end the development would easily lead to a rapid decline. An ideal waterfront development project is hoped to create a win-win situation, but in the reality of development projects, we can easily find that many waterfront development projects cannot achieve the ideal, and an inappropriate waterfront development strategy is one of the important reasons why it is unable to reach the ideal.

\section{The Classification of Waterfront from the Third-Wave Concept}

Because different types of waterfront have different space requirements, it is essential to make classification of the waterfront before waterfront development. There are many different classification methods for waterfront; in Design and Development of Urban Waterfront, waterfront is approximately divided into the following classifications in views of location and function [19]:

1 Ecological protection zone.

2 New development.

3 Rebuilding of old industrial areas.

4 Connected to residential area.

5 Connected to downtown area.

6 For leisure and travel.

In 1985, according to development patterns, Breen \& Rigby classified water into commercial type, cultural and educational environment type, historic type, entertainment type, housing type, and work type, of which work type refers to the commercial port and fishing port needing labor and machinery [23], but as for the current trends of waterfront development in different countries, particularly the waterfront mainly focusing on service industry as the main development pattern, its function and development tend to be diversified, so as long as there is no problem in compatibility, such development shall be basically rather easy to create a multiplier effect, thus to make waterfront development more successful.

According to waterfront activities, Vallega mentioned 12 kinds of major waterfront activities [24]; Toffler in his Third Wave series [25], clearly expounded his "third-wave" concept: The first wave refers to the agricultural era in $10,000 \mathrm{BC}$, the mankind got rid of nomadic lifestyle, and people settled down in fixed lives area, and began to develop towns and their own culture. The second wave was starting from the 18th century; taking the opportunity of "Industrial revolution", people left the farm and flocked to the cities to make a life in the factory. The third wave was another big change of the human mind -"Information revolution", where information technology and social needs were the powerful driving force for its development, the whole world melted together, and people sought for cooperation without national boundaries.

Past studies divided waterfront into many types, but didn't further elaborated the functions or association of various waterfront types; this study will attempt to construct three stages and six types classification and evolution model for 
The development and application of waterfront land is related to several important revolutions, first of all in agricultural time, the changes in the waterfront took place very slowly, and the industrial transformation period is also very long. The emphasis of the relation between humanity and waterfront is the "life" and the function styles are aquaculture and fishing, and offshore fishing. The primary performances are fishery, traditional fishing and operation on fishing grounds, the industry type belongs to "Added-value labor" and this paper has treated this waterfront development as the first stage waterfront. With the coming of "Industrial Revolution Era" industrial structure has changed greatly and the change period relatively accelerates, the emphasis of the humanity and waterfront relation is the "logistics production" its function styles are distributed processing, logistics and trade, the primary performances are goods distribution, processing intermediary, international logistics and trades stream, and the industry type belongs to "Added-value production". This paper has entitled this waterfront development as the second stage waterfront. With the coming of "Information Revolution Era" the changes in industrial structure become more intense; the change period becomes even faster, the emphasis of human and waterfront relation is "ecosystem" its function styles are leisure and tourism, research experience, its primary performances are recreation, tourism, cultural preservation, marine research and ecosystem investigation, and the industry type belongs to "Added-value service". This paper has treated this waterfront development as the third stage waterfront. In the future, the functions of the waterfront will be further diversified, and the development of waterfront will stop the enlargement without limitation with the rise of sustainable development, and the concept of protecting waterfront will be paid special attention, the development and management of the waterfront supplements each other, and the relation between city and different stages and types of waterfront will be established on "sustainable life" [26-27].

Actually many of the documentaries about waterfront concern about the third stage waterfront, the "Added-value service" type, or the "Post-Industrial Revolution" stage waterfront. But waterfront in a general sense includes the entire waterfronts that are mentioned above. The waterfront applications of different stages have their own time background and space demand according to the theory of waterfront development. And even the waterfront of the same city may often have different types. The space layout, infrastructure and the implantation of traffic of the former waterfront all aim at the special needs of that particular time. Therefore it should not be transformed hurriedly when the function of the inherent stage is still active. On one hand, this consideration is because the cost for compulsive transformation will be relatively higher, and on the other, the transformation of the urban industry and population structure cannot be finished in a short time. When the urban industry population still needs the current type of waterfront, the compulsive transformation will cause a negative impact on the urban industrial structure, even cause rebound. Therefore the transformation will only happen after the obvious shrinking and degrade of the waterfront function under current stage [28-29].

Besides, combining the concept of conservation and sustainable development, this study proposed that waterfront development can be divided into three categories according to the development strength, namely maintenance, renovation and renewal. Human kinds develop and make use of waterfront for different reasons, but as people realize the importance of environment and ecology, waterfront management concepts are paid more and more attention to, and waterfront is no longer endlessly developed. At the moment waterfront is unavoidably developed, we try to moderate the consumption of waterfront resources, based on the concept that maintenance is superior to renovation, and renovation is superior to renewal. First, undeveloped waterfront should be kept it original unless absolutely necessary and precious waterfront ecology should be especially maintained; second, for developed waterfront, we should respect its original development function, so we renew the waterfront only when the original staged function of the waterfront has obviously declined, and modest waterfront management measures are also absolutely necessary.

\section{Origin, Significance and Content of Waterfront Development Strategy}

The factors influencing the waterfront development are complicated. From the cases in the world view, the success of a waterfront development project needs very careful scheming of all aspects including development strategy, planning, design, operation, management, and etc., each of which are indispensable; usually serious mistakes of a single part involves may lead to failure of the entire project, so to discuss this issue, we must make an integral consideration. In the book Design and Development of Urban Waterfront, it is mentioned that success factors of waterfront development are as follows [19]:

1 Deliberate development strategy (Strategy).

2 Careful planning and innovative design (planning).

3 The main building is the key (Architectural Design).

4 Attach importance to management to maintain the attraction of waterfront area (operation and management).

Waterfront development includes political decision-making, urban planning, architectural design, development operation and management; the land development strategy mentioned in this paper focuses not only on the development of points, but also on the development of lines and surfaces.

The waterfront land development strategy and urban development strategies are closely related; more precisely, waterfront land development strategy is one part of urban 
development strategy [30]. At different stages and for different problems, we need different development strategies; for analysis of waterfront land development strategy, this paper will explain in two aspects: the origin and significance of strategy, and the contents of strategy:

(A) The origin and significance of strategy

Strategy originates to solve the problems we face; for the problems we face, the paper will consider from three surfaces: the past, the present and the future:

1 Why such a problem was created in the past?

2 How do we solve the problem now?

3 What is our vision in the future to solve these problems?

With respect to the thinking aspects of these three questions, the significance of development strategy can be divided into the following three points:

1 Make up for the deficiency of existing mechanisms: Many problems ignored in the past resulted in development deficiency, so since some problems have been created, we proposed the development strategies to make up for the deficiency of existing mechanisms.

2 Deal with new problems appearing during the development: For different time and space conditions, it is necessary to adjust the functional orientation, spatial structure, development direction and other major issues during the development, and propose the development strategies to cope with the new problems.

3 Depict conception for the future development prospects: Based on concern and understanding of the economic, environmental, and social changes, and in combination of the experience operation and theoretical research and analysis, propose development strategies to depict conception for the future development prospects of the solved problems.

Opposite to waterfront development strategy, another is to think about no waterfront development strategy, i.e. despite the free development of waterfront. In fact, despite the land with idle waterfront brought opportunities for urban development, we also learned from many development cases that no waterfront development strategy or improper development strategy may still cause the failure of the waterfront development.

As for the waterfront development strategy, in the sight of development experiences of countries in the world, generally government occupied an leading position; although a good strategy couldn't ensure the success of development projects (still need to the cooperation of other relevant factors), in the sight of development experiences of countries in the world, laissez-faire market operation or wrong strategies almost caused failure without exception, of development cases in London, England were most representative [31]. Taking Canary Wharf in London as an example; the government completely abandoned planning and control early by laissez-faire market operation, and this in some ways meant contempt of the status of planning teams and planners. As a result, certain specific locations with a profit-making nature indeed succeeded in a short term, but due to lack of development strategy for the whole region, specific locations with nonprofit-making nature cannot be taken care of and their developmental delay lead to failure of the whole region. In addition, taking the waterfront development in Copenhagen, Denmark as an example; the development was originally controlled by the government, and later due to the development efficiency, the government agency established a company, thus the development was in the charge of private sectors and enterprises; as a result, the efficiency was indeed considerably improved, but the development project was criticized for ignoring the interests of people living in the development region. The criticism also adversely affected the entire waterfront development project [32]. And then take the waterfront development in the Rocks and Woolloomooloo, Australia as examples; due to lack of support from trade union federation, the working class residents and the middle-class conservatives, the development projects in the two regions were frustrated. Many waterfront development strategies ignored people's rights, and put excessive emphasis on the efficiency; generally, the interests of the people living in the development region were not taken seriously, especially the interests of local low-income residents were often trampled and sacrificed; on this point, even Baltimore, the city often used as a model of success was of no exception. Through interview statistics, American scholar Krausse, G. H (1995) [33] explored the feelings of residents in Newport, Rhode Island, the U.S. on tourism development and waterfront redevelopment, as well as changes of demographic and social structure. The development project made a large number of residents migrate outward. Such a phenomenon was greatly related to the fact that local residents' opinions were not included in the early development strategies. The four articles written by Brett, E. A. (2000), Ryan, C., Cooper, C. (2000), Bassett, K., Griffiths, R. and Smith, I. (2002), Brusbett, K. (2003)[34-37] all emphasized the importance of residents' participation during the development and planning process; many papers also noted the drawbacks of failure in including the public's opinions in the planning phase; and some literature about the waterfront development repeatedly mentioned the importance of including the public's opinions. In this case, the waterfront development in Canada developed a unique form because of its developed community organizations, and it was much precious that the rights of people living in the development region were considered $[2,38]$. In the future this trend will be attached much importance on to make development strategies more perfect.

(B) Contents of strategy

The conditions of waterfront in each city are not the same, so the design of waterfront land development strategy shall be based on the conditions and problems of each city's waterfront in each; therefore, when designing the waterfront development strategies, the first things shall be to make SWOT analysis of the city's waterfront development conditions, in order to make a systematic understanding of the strengths, weaknesses, opportunities and threats to be engaged in waterfront development. Only after the above analysis, can 
we work out the content of waterfront development strategy, which is mainly divided into the five categories:

1 Waterfront development orientation: In a city, there may be many waterfront development units of different types and levels, and waterfronts of different type and level shall have different orientation, and the waterfront development orientation shall take into comprehensive consideration of the international community, the country's city division, and the city's development vision. Different types of waterfront also have different space requirements, so the waterfront development orientation is the primary content to design the waterfront development strategy, so as to make a clear direction for the waterfront development. In terms of the three stages and six types waterfront development and development strength concerned in this paper, it is necessary to find out the waterfront development orientation after a comprehensive analysis, and to distinguish which shall be orientated as the first, second and third stage of waterfront? Which need to be maintained? Which remain the original function and only renovation to improve the original function? And which need renewal and reconstruction?

2 Waterfront development layout: besides analyzing the waterfront according to the conditions and orientation, it is also necessary to analyze the waterfront development layout, so that the city's waterfront can be considered from a point level to a line and surface level. Considering whether the waterfront development involves functional or regional conflicts, and how to melt waterfront development layout into the urban development layout, the layout will naturally include in transportation planning, infrastructure, water quality and other relative constructions. In this general direction of layout, individual waterfronts develop gradually and the city will ultimately obtain development advantages.

3 Dimension and depth of waterfront development: The considered dimension and depth of waterfront development will affect the future development patterns and success or failure. An advanced dimension of waterfront development, developed in that it originally only considered the economic side, but now takes into account of environmental side, social side and sustainable development; and as for the angle from which it considers changed from the previous government to the stand of planner team, developers, and people. In the future, a successful waterfront development strategy will emphasize deep and diverse thinking.

4 Selection of the implementation mechanisms: Among the waterfront development experience in various countries, the implementation mechanisms of waterfront development, as for the management system, can be generally divided into the overall management type and decentralized management type, but most successful development experience indicated that it is easier to succeed if there is an overall management unit to control the overall situation of the development; As for the development systems, it is flexible depending on the local government's financial situation, basically necessary to classify the attribute of the development units, and then hand them over to different development agencies. According to the attribute, the development units of non-profit-making can be handed over to government agencies; the profitable development units can be handed over to the developers; whether choose a third sector organization of public-private partnerships or non-profit agencies as a development mechanism can be also adjusted according to the local political and economic systems; a large-scale waterfront development plan often takes decades to implement, so there is inevitable financial risks, so if different units are separately developed under the control of the co-ordination department, it can not only average the risks, but also can improve the development efficiency.

5 Decisions on the development order: The waterfront land development cannot be independent of urban development, so as for the external conditions of waterfront development, transport planning, infrastructure, water quality and other constructions are like umbilical cord and nutrients supplying waterfront land development. When these projects can be completed first, the waterfront land development will be easy to succeed; otherwise, the waterfront land development will be easy to mess up. Sometimes, the base condition of waterfront development is not all point-like, and sometimes it is linear; or several development units constitute a surface base type, and the development of different bases often influences each other, therefore, it is quite necessary to gradually ensure to the success rate of all development units. It is suggested that waterfront development units be divided into a number of development blocks. About development order of waterfront developed by different departments, it is generally recommended to first start from unit small and easy to succeed, in order to drive the development of the whole region through accumulating small victories into larger ones.

\section{The Analysis of Waterfront Development Strategy-Taking Keelung City as an Example}

This paper will take Keelung as an example to illustrate the above analysis on waterfront development strategy. Keelung is in the northeast of Taipei City, the capital of Taiwan, with the current population of 400,000. In 1970s, Keelung was one of the five metropolises in Taiwan, and Keelung Port locates at the city center of Keelung. The industrial development of Keelung used to highly count upon the container import-export industry of Keelung Port. In 1990s, Keelung Commercial Port has brought more than half of revenue taxes for Taiwan due to the continuous prosperity and the prevailing 
of shipping commerce, and it also brings along the local industrial boom indirectly. According to the master thesis "Study on the economic impact of Keelung Port container import-export industry on Keelung City" written by Tsai (1999) [39], the industry directly or indirectly related to container import-export industry of Keelung Port has reached $74.41 \%$ of the total in 1998 , and the industrial population directly or indirectly related to it has reached $82.21 \%$ of the total population. While due to intense competition from the outer world as well as $95 \%$ of the urban lands are hills which have left limited development hinterland, Keelung City has many problems to overcome while matching towards the $21 \mathrm{st}$ century. While Keelung Port hangs together with the city center of Keelung City, Keelung used to be the most important ports in north Taiwan, the harbor depth and the development hinterland cannot meet the large-scale of the vessels due to the competition from other cities. After an overall consideration, Taiwan government has officially decided to build a Taipei Newport $60 \mathrm{~km}$ west of Keelung in 1997 (See Figure 3), this policy has directly influenced Keelung City. The economic structure of Taiwan has gradually changed to depend more on the Added-value service. A lot of deserted or low-use rate land floods along the city waterfront with the downfall of industries related to Keelung Port and the littoral industrial district. Furthermore the fishery of Keelung used to play a major role in Taiwan, but in recent years, the yield of fishery in fishery harbor reduces greatly with the recent year global climatic variation, ocean pollution, and overfishing. The traditional fishery harbor function cannot maintain the development of fishing village, the outflow of population and the desertion of harbor facilities become more and more serious [40]. The decay of activities in Keelung waterfront has directly influenced the local economic development and the civil quality of life; it has also generated much chaos in society. These factors have made Keelung Port face industry transformation pressure. The 29.6 long shoreline of Keelung City are the beach and rocky shore with abundant of ocean resources. Cooperating with the historic sites, this deflecting, rich coast and tidal zones have great potential for sight-seeing, the development of tourism has become an import option for Keelung industry transformation.

To improve the usage on the waterfront land, Keelung City has made many waterfront development plans on the more than $10 \mathrm{~km}$ long coastline. But the current Keelung City waterfront development plans have many conflicts among them themselves because they belong to different ruling units and the each does things in its own way. Waterfront development plans lack the true basic object which is good for the long-term development of the city. What's more, the scales and properties of these waterfront development plans are different, their location-chosen and development manners are not all reasonable, which have restricted the more reasonable development of Keelung City waterfront land. Actually the low usage rate of Keelung City waterfront land has impacted the urban competitive power, In the future, Keelung Port needs to establish a set of favorable urban development policy to meet the demand of city transformation development, and it must make great changes in the waterfront development mode.

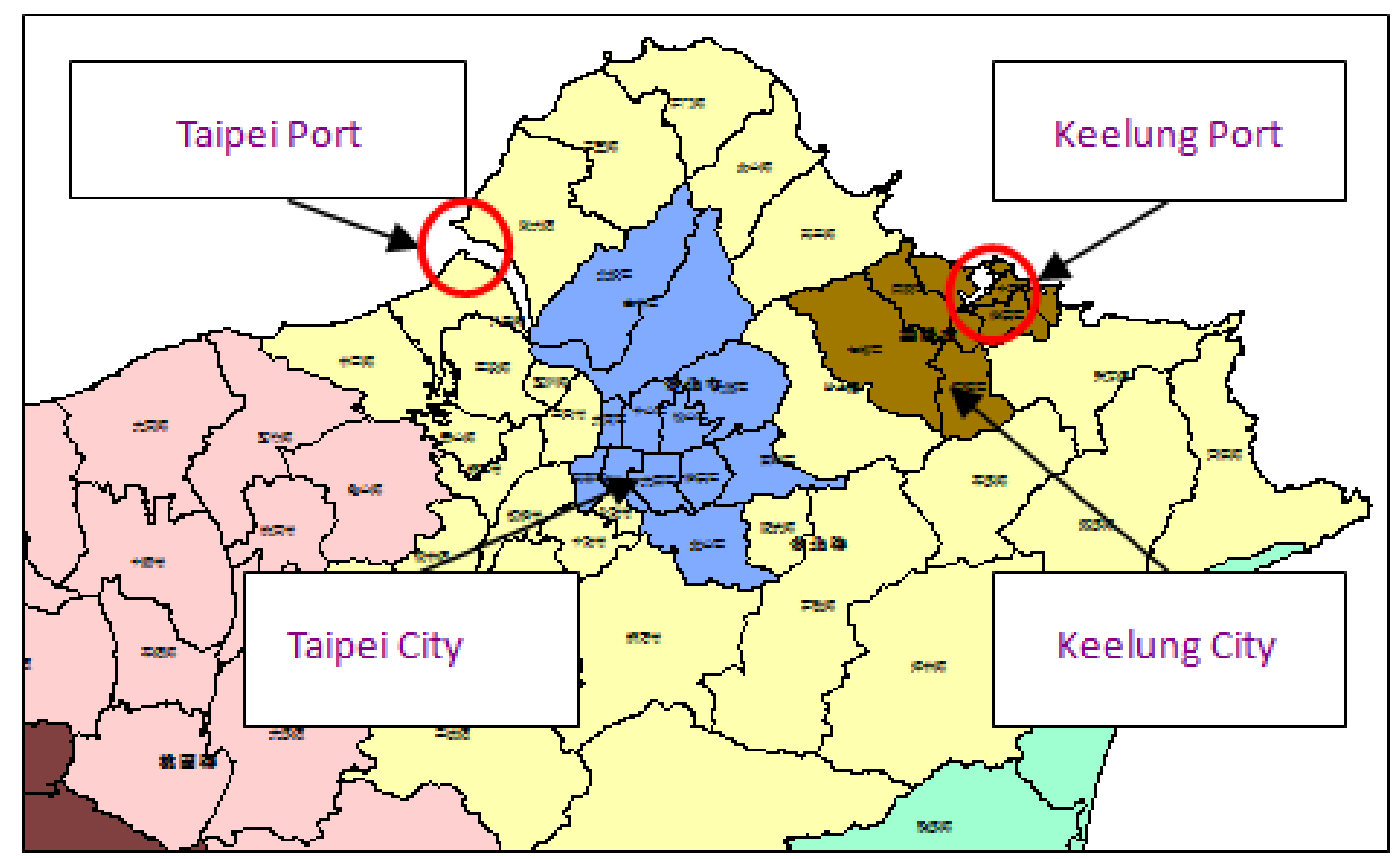

Figure 3. The location diagram of the Taipei Port and Keelung Port.

In terms of the number of existing vessels, Keelung city doesn't need so many fishing ports any longer. To make the fishing ports more efficiently used, according to research and analysis of this paper, among the fishing ports in Keelung, we only need to reserve Waimushan fishing port, Chengbing fishing port, and Batoutze fishing port as enough for existing vessels. Those the future function of which has obviously declined, such as Dawulun fishing port, Changtanli fishing 
port, and Wanghaihsiang fishing port, can be developed towards the third stage waterfront. Among them, the function of Chengbing fishing port is declining continuously; although it is maintained as the first stage waterfront at present, in the future a part of it will be released and developed as the third stage waterfront. As for the second stage of waterfront development, since the construction of Taipei Newport, it is expected that the container traffic will be difficult to rise in the future, so it is expected to be able to handle future container traffic only if leaving the West Coast container port which maintains a strong container function as the second stage waterfront; the East Coast container port the container function is reducing is currently maintained as the second stage waterfront, and in the future a part or all of it will be released as the third stage waterfront [41]. In addition, the Harbor-surrounding downtown trading area located in the inner port is fairly a large renewal development project, including waters and land two parts, with a total area of 97.08 hectares, of which the land area accounted for 71.31 hectares and is divided into seven units. Excluding financing for external infrastructure facilities, the amount invested in hardware construction of bases is estimated more than USD one billion [42]. Due to function recession of the inner port, in the future the inner port will be renewed as the third stage waterfront; Dawulun Waimushan coast, Hoping Island Geological Park, and Changtanli Tidal Flat Ecological Park will be maintained and conserved for there are precious coastal and embroidery rock zoology, biological traces and fossil which is rare rocky coast zoology, intertidal zone zoology and etc. valuable coastal ecosystems.

Actually, concerning the scattered locations of the present waterfront development in Keelung harbor city, there are many advantages in transformation to tourism. The text summarizes as follows:

1. Waterfront development locations are temperate distribution.

2. Close to the downtown.

3. Diversity of waterfront.

4. Waterfront possess many rare ecosystem.

5. A good number of traveling and rest sites around the waterfront.

After referring The Report on the Overall Review of the Enlargement and Alteration of Major Program of Keelung City (1998) [43], The Comprehensive Development Program of Keelung City (2000) [44] and a master's thesis written by Wen-Hsin Lin-Research on Fishing Port Multifunctional Development Strategies - A Case Study in Keelung (2006) [45], and other literature, this paper made SWOT analysis of the functions of all Keelung waterfronts and fishing ports, and made classifications like this: fishing ports suited to the first stage development include Waimushan fishing port, Chengbing fishing port, Batoutze fishing port; those more suited to sustain the second phase development include West Coast Container Port and Keelung East Coast Container Port; those more suited to sustain the third stage development include Dawulun fishing port, Harbor-surrounding downtown trading area, Bisha fishing port, Changtanli fishing port, and
Wanghaihsiang fishing port.

Classified by the standards of maintenance, renovation and renewal, Dawulun Waimushan Coast, Hoping Island Geological Park and Changtanli Tidal Flat Ecological Park are suitable to be maintained; Dawulun Fishing Port, Waimushan Fishing Port, Keelung West Coast Container Port, Keelung East Coast Container Port, Bisha Fishing Port, Batoutze Fishing Port, Changtanli Fishing Port, and Wanghaihsiang Fishing Port are suitable to be renovated; and Harbor-surrounding downtwon trading area is suitable to be renewed.

According to the development blocks, the research, after analysis, broadly divided into Dawulun Waimushan fishing port block, harbor-surrounding downtown trading block, Hoping Island Chengbing fishing port block, Batoutze Bisha fishing port block, and Changtanli Wanghaihsiang fishing port block [46-47]. In terms of spatial patterns and internal and external conditions, considering the compartment of waterfront development patterns, harbor-surrounding downtown trading block can be used as "Harbor waterfront of local color", due to "Renewal Program of Central Business District of Keelung City" launched by Keelung City Government [42] and this region combining the city business center specialty. As for Hoping island Chengbing fishing port block, the Keelung City Government launched the "National Door Shanhaikwan Program Integrated Program Of Landscapes Around keelung City Bisha Fishing Port” [48], which divided Hoping Island into three development units: Hoping Island geological park, romantic town, and mountainous products street; combined with the future restructuring and development of Chengbing fishing port, it can be used as "Town waterfront of culture fascination". As for Batoutze Bisha fishing port block, according to the plan made by the Keelung National Museum of Marine Science and Technology [49], and combined with local Ocean University and etc. academic institutions, it can be used as "Integrated educational science and technology garden waterfront".

In terms of the development order of the blocks, according to the analysis of this research, The Bisha fishing port included in Batoutze Bisha fishing port block has transited to a tourism fishing port to be developed as the third stage, and there will be built an world-class maritime museum to its east, the waterfront land in this block is advantaged and should be the best place of top priority to develop. Following it, the Changtanli Wanghaihsiang fishing port block, located in the south-east of the maritime museum is also close, it has a great potential to be developed as the third stage waterfront, so it should be considered as the second priority to develop. With the only beach of the city and precious coastal and embroidery rock zoology, and not difficult to develop, The Dawulun Waimushan fishing port block can be regarded as the third priority to develop. And then followed was Hoping island Chengbing fishing port block; because of a larger area to develop and some difficulties to overcome, it can be considered as the fourth priority. Finally shall be the harbor-surrounding downtown trading block which is the 
most difficult to develop (See Figure 4 and Table 4).

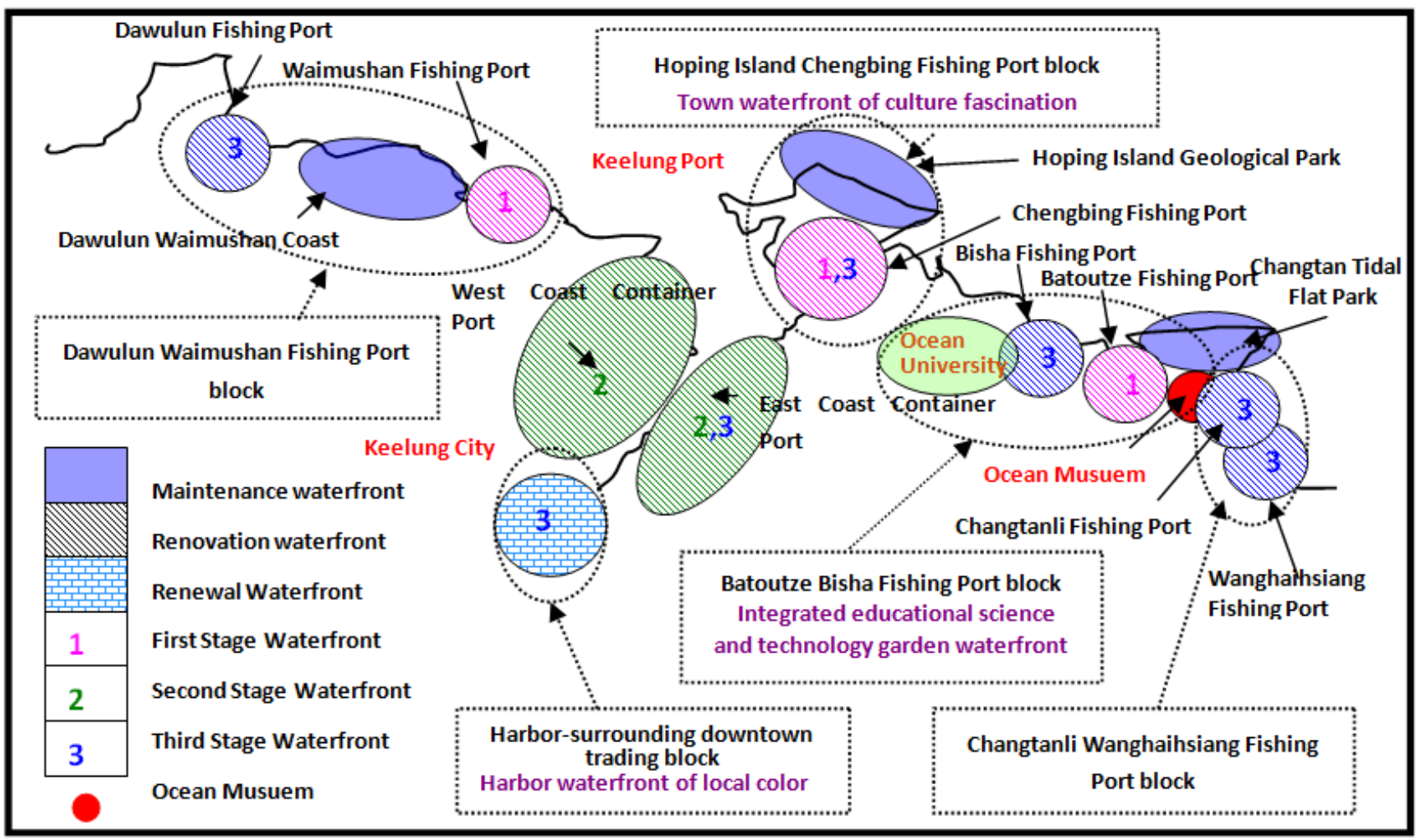

Figure 4. Diagram of distribution of waterfront development in Keelung City.

Table 4. Table of phases of waterfront development of Keelung City.

\begin{tabular}{|c|c|c|c|c|}
\hline \multicolumn{2}{|c|}{ Development area and development block } & \multirow{2}{*}{$\begin{array}{l}\begin{array}{l}\text { Stage of } \\
\text { development }\end{array} \\
3\end{array}$} & \multirow{2}{*}{$\begin{array}{l}\text { Development } \\
\text { intensity }\end{array}$} & \multirow{2}{*}{$\begin{array}{l}\text { Explanatory comment } \\
\text { Fishery port function weakens and transformation into } \\
\text { the third-stage waterfront }\end{array}$} \\
\hline & Dawulun Fishing Port & & & \\
\hline $\begin{array}{l}\text { Dawulun Waimushan Fishing } \\
\text { Port block }\end{array}$ & Dawulun Waimushan Coast & - & Maintenance & $\begin{array}{l}\text { Contains precious coastal and embroidery rock } \\
\text { zoology and need preserving and maintaining }\end{array}$ \\
\hline \multirow{4}{*}{$\begin{array}{l}\text { Harbor-surrounding downtown } \\
\text { trading block (Harbor } \\
\text { waterfront of local color) }\end{array}$} & Waimushan Fishing Port & 1 & Renovation & $\begin{array}{l}\text { Remains an active fishery harbor function and need be } \\
\text { kept as first-stage waterfront }\end{array}$ \\
\hline & West Coast Container Port & 2 & Renovation & $\begin{array}{l}\text { Remains an active container function and need be kept } \\
\text { as second-stage waterfront }\end{array}$ \\
\hline & $\begin{array}{l}\text { Harbor-surrounding } \\
\text { downtown trading area (all } \\
\text { together seven renewal } \\
\text { development units) }\end{array}$ & 3 & Renewal & $\begin{array}{l}\text { Inner harbor function is weakening and will become } \\
\text { the third-stage waterfront in a new way }\end{array}$ \\
\hline & East Coast Container Port & 2,3 & Renovation & $\begin{array}{l}\text { Container function weakening and kept as the } \\
\text { second-stage waterfront. Parts of the district will be } \\
\text { released as the third-stage waterfront }\end{array}$ \\
\hline \multirow{2}{*}{$\begin{array}{l}\text { Hoping Island Chengbing } \\
\text { Fishing Port block (Town } \\
\text { waterfront of culture } \\
\text { fascination) }\end{array}$} & Chengbing Fishing Port & 1,3 & Renovation & $\begin{array}{l}\text { Fishery harbor function weakening and kept as the } \\
\text { second-stage waterfront. Parts of the district will be } \\
\text { released as the third-stage waterfront }\end{array}$ \\
\hline & $\begin{array}{l}\text { Hoping Island Geological } \\
\text { Park }\end{array}$ & - & Maintenance & $\begin{array}{l}\text { Containing biological traces and fossil which is rare } \\
\text { rocky coast zoology and requiring maintenance and } \\
\text { preservation }\end{array}$ \\
\hline \multirow{3}{*}{$\begin{array}{l}\text { Batoutze Bisha Fishing Port } \\
\text { block ( Integrated educational } \\
\text { science and technology garden } \\
\text { waterfront) }\end{array}$} & Bisha Fishing Port & 3 & Renovation & $\begin{array}{l}\text { Fishery harbor function weakens and transformation } \\
\text { into the third-stage waterfront }\end{array}$ \\
\hline & Batoutze Fishing Port & 1 & Renovation & $\begin{array}{l}\text { Remains an active fishery harbor function and need be } \\
\text { kept as first-stage waterfront }\end{array}$ \\
\hline & $\begin{array}{l}\text { Changtanli Tidal Flat } \\
\text { Ecological Park }\end{array}$ & - & Maintenance & $\begin{array}{l}\text { Containing rare intertidal zone zoology and requiring } \\
\text { maintenance and preservation }\end{array}$ \\
\hline \multirow[t]{2}{*}{$\begin{array}{l}\text { Changtanli Wanghaihsiang } \\
\text { Fishing Port block }\end{array}$} & Batoutze Fishing Port & 3 & Renovation & $\begin{array}{l}\text { Fishery harbor function weakened and transformed } \\
\text { into the third-stage waterfront }\end{array}$ \\
\hline & $\begin{array}{l}\text { Wanghaihsiang Fishing } \\
\text { Port }\end{array}$ & 3 & Renovation & $\begin{array}{l}\text { Fishery port function weakened and transformed into } \\
\text { the third-stage waterfront }\end{array}$ \\
\hline
\end{tabular}


Despite of the excellent development conditions of Keelung waterfront, after reviewing with the waterfront land development strategy discoursed in this study, the waterfront development plan currently proposed by the Keelung City Government and etc. units still has many strategic errors:

1 There is no coordinated planning and management units for these waterfront development plans.

2 The waterfront development plan lacks overall consideration.

3 The development orientation of each waterfront development unit is not clear.

4 The considerations for waterfront development lack dimension and depth.

5 Transportation planning network and other infrastructure are not complete.

6 Public participation mechanisms and channels are not sound.

7 The operational management mechanisms should to be improved.

Taiwan's waterfront development has been behind advanced countries in the world for nearly three decades, but from another point of view, because of its slow start, it can absorb much experience of advanced countries in the development; however, the experience of successful waterfront development cannot be completely copied after all. During waterfront development, on the one hand we can refer to the development experience of similar cases around the world; on the other hand, it is essential to comprehensively consider the basic conditions of individual cases, the organizational structure of local government, the prevailing economic and fiscal conditions, and so other factors. The waterfront development of Keelung Harbor is also in its infancy, so we may learn the development experience of many foreign counties. The waterfront land development strategy analysis in this paper can be provided for Keelung government agencies and relevant units wishing to engage in waterfront development as reference.

\section{Conclusion}

Waterfront development is a worldwide phenomenon, and there are also a lot of trial error and learning processes. The waterfront transition problem faced to Keelung Harbor is an epitome of many other port cities facing the same problem; in the future the considered dimension and depth of waterfront development will continue to evolve, and we need to think from more diverse angles. When we know the preciousness of waterfront, waterfront development project should not only consider the factor of engineering technical. In particular, the consideration of systematic planning and sustainable management is absolutely necessary. Waterfront development involves very complex factors, so it is necessary to refer to cases of countries in the world, in order to minimize the possibility to make the same mistakes. For waterfront development, a good strategy is the first step; as different types of waterfront involve different concepts in space requirements, this paper attempts to use Third Wave developed by Alvin Toffler in 1980, to construct the three stages and six types classification and evolution relationship of waterfront development, and then incorporate sustainable development concept to classify the waterfront development strength into maintenance, renovation, and renewal, in order to illustrate the functional structure and development mode of different stages. In addition, Keelung port city was taken as an example to illustrate how to apply these ideas to the current Keelung waterfront land development strategy, thus to view the defects of Keelung waterfront land development strategies. Because waterfront development in different cities has its own unique conditions, it is not easy to set an absolute standard, but from the cases of countries in the world, there is still theoretical and spatial commonality among successful cases, worth learning. The successful experience of others was a result under certain political, economic, and geographic conditions, so when we learn the successful experience, we should learn its principles and ideas instead of copying its appearance and styles, so as to naturally improve the success rate of waterfront development. These concepts and principles are important implications for those countries wanting to develop waterfront plan.

\section{References}

[1] Hayuth, Y. (1998). Changes on the waterfront: a model-based approach. In: Hoyle, B.S., Pinder \& MS Husain, D.A. (Eds.), Revitalising the Waterfront: International Dimensions of Dockland Redevelopment. Belhaven Press, Great Britain, pp.52-64.

[2] Hoyle, B. (1999). Scale and sustainability: the role of community croups in Canadian port-city waterfront Change. Journal of Transport Geography, 7:65-78.

[3] Vallega, A. (2001a). Urban waterfront facing integrated coastal management. Ocean \& Coastal Management, 44:379-410.

[4] Al-But'hie, I.M., Saleh, M.A.E. (2002). Urban and industrial development planning as an approach for Saudi Arabia: the case study of Jubail and Yanbu. Habitat International, 26(1): $1-20$.

[5] Alters, W.K.K. (2002). Local government and the decentralization of urban regeneration policies in the Netherlands. Urban Studies, 39(8):1439-1452.

[6] Chen, K.Y. (2007). System Planning for the Development of Keelung Port City Waterfront, Master's thesis, Graduate Institute of Harbor and River Engineering, National Taiwan Ocean University, Keelung.

[7] Hoyle, B. (2000b). Global and local change on the port-city waterfront. The Geographical Review, 90(3):395-417.

[8] Gladstone, D.L. (1998). Tourism urbanization in the United States. Urban Affairs Review, 34(1):3-27.

[9] Huang W., Corbett J.J., \& Jin D. (2015). Regional economic and environmental analysis as a decision support for marine spatial planning in Xiamen. Marine Policy, 51:555-562. 
[10] Gordon, D.L.A. (1997). Managing the changing political environment in urban waterfront redevelopment. Urban Studies, 34(1):61-83.

[11] Cuesta Camacho, D.E. (1998). Environmental injustices, political struggles: race, class and the environment. Duke University Press, Michigan United States.

[12] Gordon, D.L.A. (1999). Implementing urban waterfront redevelopment in an historic context: a case study of The Boston naval shipyard. Ocean \& Coastal Management, 42(10-11):909-913

[13] Flood S., Schechtman J. (2014). The rise of resilience: Evolution of a new concept in coastal planning in Ireland and the US, Ocean \& Coastal Management, 102:19-31.

[14] Korbee D., Mol A.P.J. \& Tatenhove J.P.M.V. (2015). Ecological considerations in constructing marine infrastructure: The Falmouth cruise terminal development, Jamaica. Marine Policy, 56:23-32.

[15] Baird, A. (1999). Analysis of private seaport development: the port of Felixstowe. Transport Policy, 6(2):109-122.

[16] Dovey, K., Sandercock, L. (2002). Hype and hope: Imagine Melbourne's docklands. Cities, 6(1):83-101.

[17] Keith, B., Ron, G. \& Ian, S. (2002). Testing governance: partnerships, planning and conflict in waterfront regeneration. Urban Studies, 39(10):1757-1775.

[18] Keith, J. (2004). Waterfront redevelopment: a critical discourse analysis of the policy-making process within the Chatham maritime project. Urban Studies, 41(4):817-832.

[19] Chang, T.C., Feng, H., Peng, C.C. (2001). Design and Development of Urban Waterfront, Tong Ji University Press, Shanghai.

[20] Malone, P. (1999). City, capital and water. Tsang Hsin Press, Taipei.

[21] Batley, R. (1996). Public-private relationship and performance in service provision. Urban Studies, 33(4/5):723-751.

[22] Huang, W.C., Kao, S.K. (2014). Public-private partnerships during waterfront development process: The example of the world exposition, Ocean \& Coastal Management, 92:28-39.

[23] Breen, A., Rigby, D. (1985). Caution: Working Waterfront the Impact of Change on Marine Enterprise. The Waterfront Press, Washington.

[24] Vallega, A. (2001b). Ocean governance in post-modern society: a geographical perspective. Marine Policy, 25:399-414

[25] Toffler, A. (1980). The third wave. Bantam Press, New York.

[26] Huang, W.C., Chen, C.H., Kao, S.K. \& Chen, K.Y. (2011). The concept of diverse developments in port cities, Ocean \& Coastal Management, 54:381-390.

[27] Chen, C.H. (2011). A Study on the Development Concept and Strategies of Waterfront, $\mathrm{PhD}$ thesis, Graduate Institute of Harbor and River Engineering, National Taiwan Ocean University, Keelung.

[28] Gleave, M.B. (1997). Port activities and the spatial structure of cities: the case of Freetown, Sierra Leone. Journal of Transport Geography, 5(4):257-275.
[29] Kojima H., Kubo T., Kinoshita A. (2013). Integrated coastal management as a tool for local governance of coastal resources: A case study of Munakata coastal zone. Ocean \& Coastal Management, 81:66-76.

[30] Huang, K.Y., Chu, H.Y. (2003). Theory and Planning Method of Ecological City, Science Press, Beijing.

[31] Church, A. (1988). Demand-led planning, the inner-city crisis and the labour market: London Docklands evaluated In: Hoyle, B.S., Pinder \& MS Husain, D.A. (Eds.), Revitalising the Waterfront: International Dimensions of Dockland Redevelopment. Belhaven Press, Great Britain, pp.199-221.

[32] Desfor, G. (2004). Flexible urban governance: the case of Copenhagen's recent waterfront development. European Planning Studies, 12(4):479-496.

[33] Krausse, G.H. (1995). Tourism and waterfront renewal: assessing residential perception in Newport, Rhode Island, USA. Ocean \& Coastal Management, 26(3):179-203.

[34] Brett, E.A. (2000). Participation and accountability in development management. The Journal of Development Studies, 40(2):1-29.

[35] Ryan, C., Cooper, C. (2004). Residents' perceptions of tourism development: the case of Raglan, New Zealand. Tourism Review International, 8(1):1-15.

[36] Bassett, K., Griffiths, R. \& Smith, I. (2002). Testing governance: partnerships, planning and conflict in waterfront regeneration. Urban Studies, 39(10): 1757-1775.

[37] Brusbett, K. (2003). , "People and government traveling together" community organization urban planning and the politics of post-war reconstruction in Toronto 1943-1953. Urban History Review, 27(2):44-59.

[38] Hoyle, B. (2000a). Confrontation, consultation, cooperation? Community groups and urban change in Canadian port-city waterfronts. Canadian Geographer, 44(3):228-243.

[39] Tsai J.L. (1999). Study on the economic impact of Keelung Port container import-export industry on Keelung City. Master's thesis, Graduate Institute of Traffic and Transpotation, National Chiao Tung University, Keelung.

[40] Keelung City Government. (2001a). The History of Keelung Fishery Development. Keelung City Government, Keelung.

[41] Chen, W.S. (2001). Research on Taipei Port Development Strategy Evaluation, Master's thesis, Graduate Institute of Harbor and River Engineering, National Taiwan Ocean University, Keelung.

[42] Keelung City Government. (2001b). Renewal Program of Central Business District of Keelung City. Keelung City Government, Keelung.

[43] Keelung City Government. (1998). The Report on the Overall Review of the Enlargement and Alteration of Major Program of Keelung City. Keelung City Government, Keelung.

[44] Keelung City Government. (2000). The Comprehensive Development Program of Keelung City. Keelung City Government, Keelung.

[45] Lin, W.H. (2006). Research on Fishing Port Multifunctional Development Strategies - A Case Study in Keelung, Master's thesis, Graduate Institute of Harbor and River Engineering, National Taiwan Ocean University, Keelung. 
[46] Huang, W.C., Chen, C.H., Kao, S.K. (2005a). The resource integration and development strategy of Keelung waterfront. In: Keelung Waterfront Development Symposium. Graduate Institute of Harbor and River Engineering, National Ocean University, Keelung.

[47] Huang, W.C., Chen, C.H., Kao, S.K. (2005b). The fishing port transformation and comprehensive plan of Keelung port city waterfront. In: Fishery Industry Development and Fishing Port Development Forum. Graduate Institute of Building and Planning, National Taiwan University/Graduate Institute of
Harbor and River Engineering, National Ocean University, Keelung.

[48] Keelung City Government. (2004). National Door Shanhaikwan Program Integrated Program of Landscapes around Keelung City Bisha Fishing Port. Keelung City Government, Keelung.

[49] Keelung City Government. (2005). The Traffic Improvement Planning Surrounding Keelung National Museum of Marine Science and Technology. Keelung City Government, Keelung. 